\title{
Clinical evaluation of elderly people with chronic vestibular disorder
}

\author{
Juliana Maria Gazzola ${ }^{1}$, Fernando Freitas \\ Ganança ${ }^{2}$, Mayra Cristina Aratani ${ }^{3}$, Monica \\ Rodrigues Perracini ${ }^{4}$, Maurício Malavasi \\ Ganança $^{5}$
}

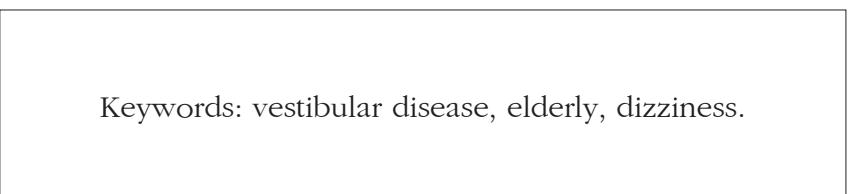

\section{Summary}

\begin{abstract}
$\mathrm{D}$ izziness is common among the elderly. Aim: To characterize social, demographic, clinical, functional and otoneurological data in elderly patients with chronic vestibular disorder. Method: A sequential study of 120 patients with chronic vestibular disorder. Simple descriptive analyses were undertaken. Results: Most of the patients were female $(68.3 \%)$ with a mean age of $73.40 \pm 5.77$ years. The average number of illnesses associated with the vestibular disorder was 3.83 \pm 1.84 ; the patients were taking on average $3.86 \pm 2.27$ different medications. The most prevalent diagnosis on the vestibular exam was unilateral vestibular loss (29.8\%) and the most prevalent etiology was metabolic vestibulopathy (40.0\%) followed by benign paroxysmal positional vertigo (36.7\%). Fifty-two patients (43.3\%) had experienced dizziness for 5 years or more. Sixty-four patients $(53.3 \%)$ had at least one fall in the last year and thirty-five (29.2\%) had recurrent falls. Conclusions: Most of the sample included females with associated diseases, and using many different drugs. The most prevalent vestibular diseases were metabolic and vascular labyrinth conditions. Dizziness is a chronic symptom in elderly patients. The association of two vestibular diseases is common. Falls are prevalent in chronic dizzy elderly patients.
\end{abstract}

\footnotetext{
${ }^{1}$ Physical therapist. Gerontology specialist trained at UNIFESP - EPM. Graduate student (Master's degree) of Sciences at the UNIFESP - EPM Otorhinolaryngology and Head \& Neck Surgery graduate course. FAPESP scholarship. Voluntary observing physical therapist at the Vestibular Rehabilitation Unit of the UNIFESP Otoneurology Department.

${ }^{2}$ Physical therapist. Gerontology specialist trained at UNIFESP - EPM. Voluntary observing physical therapist at the Vestibular Rehabilitation Unit of the UNIFESP. ${ }_{3}^{3}$ Physical therapist. Doctor in Rehabilitation Science graduated at UNIFESP - EPM. Coordinating Professor of the Physical Therapy Master's degree at the Sao Paulo City University. Voluntary observing physical therapist at the Vestibular Rehabilitation Unit of the UNIFESP.

${ }^{4}$ Full Professor of Otorhinolaryngology at UNIFESP - EPM. Senior Researcher of the Graduate Program Stricto Sensu (Master's degree) on Neuromotor Rehabilitation Science at UNIBAN. Responsible for the Otoneurological Assessment Unit of the Otorhinolaryngology Sector at the Fleury Medical Diagnostic Center - Sao Paulo (SP).

${ }^{5}$ Physician, ENT specialist, Doctor in Medicine trained at UNIFESP - EPM. Affiliated Professor of the Otoneurology Service at UNIFESP - EPM. Professor of the Neuromotor Rehabilitation Graduate Course at UNIBAN. Otoneurology Service at UNIFESP - EPM

Address for correspondence: Fernando F. Ganança - Rua dos Otonis 700 Vila Clementino 045025-002 São Paulo SP. Tel/Fax: (0xx11) 5083-4654 - E-mail: otoneuro@unifesp.epm.br Sao Paulo State Research Support Foundation (FAPESP), process number 03/10119-3.

Paper submitted to the ABORL-CCF SGP (Management Publications System) on September 25th, 2005 and accepted for publication on June 8th, 2006.
} 


\section{INTRODUCTION}

Vestibular dysfunction is a significant condition in the elderly, as age is directly proportional to the presence of multiple associated otoneurological symptoms such as dizziness, hearing loss, tinnitus, changes in body balance, gait disturbances and occasional falls, among others ${ }^{1}$.

Dizziness results from primary or secondary vestibular system disorders in approximately $85 \%$ of cases ${ }^{2}$.

Vertigo and other forms of dizziness originating in the vestibular system are frequent in the elderly. According to Ganança and Caovilla ${ }^{3}$ there are many citations on the prevalence of vertigo. It is present in 5 to $10 \%$ of the world population; it is the seventh most frequent complaint in women and the fourth most frequent complaint in men; it affects $47 \%$ of men and $61 \%$ of women over 70 years of age; it is the most common complaint in patients over 75 years of age; it is the second most common symptom in patients up to 65 years of age and the most common symptom in patients over 65 years of age; it is present $65 \%$ of persons aged 65 years and above, in $50 \%$ to $60 \%$ of the community dwelling elderly and in 81 to $91 \%$ of the elderly seen in geriatric outpatient clinics.

The most frequent otoneurological syndromes in the elderly are Benign Paroxysmal Positional Vertigo (BPPV), Ménière's Disease, Vascular Labyrinthopathies, Metabolic Labyrinthopathies, Presbivertigo/Presbiataxis/Presbitinnitus/Presbiacusis, Vestibular Neuritis, Labyrinthic Trauma, Ototoxicosis, Cervical Syndrome, Vestibular Migraine, Sudden Deafness, Immune Diseases, Vestibular Schwannoma, Vertebrobasilar Failure and Multiple Sclerosis ${ }^{2}$.

Tinetti et al. ${ }^{4}$ consider dizziness a geriatric syndrome, a multifactorial health condition that occurs due to the cumulative effect of multiple system deficits leading to increased vulnerability to circumstantial challenges in the elderly. These authors found that the activities and emotional states most frequently associated with dizziness are standing up, turning around and anxiety. They also noted that depression, balance disorders, previous acute myocardial infarction, postural hypotension, the number of medications taken, and hearing loss were clinical variables associated with an increased risk of dizziness. Furthermore, the probability of a report of dizziness was strongly associated with the number of predisposing variables.

A detailed clinical assessment looking at social, demographic, clinical, functional, and otoneurological data in the elderly with chronic vestibular disease could increase diagnostic precision and improve treatment.

The aim of this study was to characterize the social, demographic, clinical, functional, and otoneurological data of elderly patients with chronic vestibular dysfunction.

\section{METHODS}

We conducted a cross-sectional descriptive study of a sample of male and female patients aged 65 years or more with chronic vestibular dysfunction, characterized by complaints of dizziness and/or imbalance and/or presyncope and/or other non-specific feelings of dizziness for at least the last three months. Patients were included sequentially from the Otoneurology Outpatient Clinic of the Paulista Medical School which belongs to the Sao Paulo Federal University (UNIFESP - EPM).

Exclusion criteria included elderly patients with crises of vertigo, patients with severely reduced visual and auditory acuity limiting completely the activities of daily living, even with corrective lenses and/or sound amplification devices, and patients that could not walk independently or that were on wheelchairs.

This study was approved by the UNIFESP - EPM Research Ethics Committee, protocol number 01215/05. All patients included in this study read the Information Letter and signed a free and informed consent form. This trial is part of a study funded by the Sao Paulo State Research Support Foundation (FAPESP), process number 03/10119-3.

Elderly patients initially underwent a clinical otoneurological assessment including a clinical history and an otorhinolaryngological physical exam, audiometry, imitanciometry and a vectoelectronystagmographic vestibular exam according to the Ganança et al., ${ }^{2,5}$ guidelines.

Data were collected between April 2003 and November 2004.

The variables were classified into social and demographic data, clinical and functional data and otoneurological data.

Social and demographic data were gender, age, color, marital status, education level and housing conditions.

Clinical and functional data were the number of diseases, diseases as classified under the International Classification of Diseases ${ }^{6}$, the number of medications taken, drugs classified by the Anatomical Therapeutic Chemical (ATC) Classification Index ${ }^{7}$, activities, positions and symptoms related to the onset of dizziness, the use of walking aids and the occurrence of falls.

Otoneurological data included the syndromic and topographic diagnosis of the vestibular dysfunction, the number of associated vestibular conditions, the classification of vestibular dysfunction into the type of condition, the time from the onset of dizziness, the type, duration and periodicity of dizziness, the dizziness visual analog scale (VAS) and associated symptoms. 
Data description analysis was done for statistical purposes. Analysis was done using the SAS System for Windows ${ }^{8}$ software.

\section{RESULTS}

The study sample included 120 elderly patients with a diagnosis of chronic vestibular syndrome, monitored at the outpatient clinic. The average age was 73.4 years, the standard deviation (SD) was 5.77 , and the maximum age was 89 years. Social and demographic data are shown on Table 1.

Table 1. Absolute and relative frequency of social and demographic data in 120 elderly patients with chronic vestibular dysfunction.

\begin{tabular}{|c|c|c|c|}
\hline & Categories & $\begin{array}{l}\text { Absolute } \\
\text { Frequency } \\
\text { (n) }\end{array}$ & $\begin{array}{c}\text { Relative } \\
\text { Frequency } \\
\text { (\%) }\end{array}$ \\
\hline \multirow{2}{*}{ Gender } & Male & 38 & 31,7 \\
\hline & Female & 82 & 68,3 \\
\hline \multirow{4}{*}{ Age group } & $65-69$ years & 36 & 30,0 \\
\hline & $70-74$ years & 31 & 25,8 \\
\hline & $75-79$ years & 37 & 30,8 \\
\hline & 80 years or more & 16 & 13,3 \\
\hline \multirow{4}{*}{ Color } & White & 84 & 70,0 \\
\hline & Yellow & 4 & 3,3 \\
\hline & Black & 14 & 11,7 \\
\hline & Mixed & 18 & 15,0 \\
\hline \multirow{2}{*}{$\begin{array}{l}\text { Marital } \\
\text { status }\end{array}$} & Married & 66 & 55,0 \\
\hline & Not married & 54 & 45,0 \\
\hline \multirow{4}{*}{$\begin{array}{l}\text { Education } \\
\text { level }\end{array}$} & Illiterate / reads / writes & 13 & 10,8 \\
\hline & Incomplete elementary & 45 & 37,5 \\
\hline & Complete elementary & 41 & 34,2 \\
\hline & Post-elementary & 21 & 17,5 \\
\hline \multirow{4}{*}{$\begin{array}{l}\text { Housing } \\
\text { arrange- } \\
\text { ments }\end{array}$} & Alone & 16 & 13,3 \\
\hline & With 1 generation & 38 & 31,7 \\
\hline & With 2 or 3 generations & 64 & 53,3 \\
\hline & Other & 2 & 1,7 \\
\hline
\end{tabular}

The average number of diseases per individual was $3.83(\mathrm{SD}=1.84)$, with a maximum of nine associated diseases; 29 patients (24.2\%) had one or two diseases, 48 patients (40.0\%) had three or four diseases and 43 patients (35.8\%) had five or more diseases. Table 2 shows data on the prevalence of diseases classified according to the International Classification of Diseases ${ }^{6}$.

The average number of medications taken by patients was $3.86(\mathrm{SD}=2.27)$, with a maximum use of 10 medications. Table 3 shows the number of medications used and Table 4 show the classification of medications according to the $\mathrm{ATC}^{7}$.
Table 2. Absolute and relative frequency of associated diseases in 120 elderly patients with chronic vestibular dysfunction.

\begin{tabular}{lcc}
\hline & $\begin{array}{c}\text { Absolute } \\
\text { Frequency } \\
(\mathrm{n})\end{array}$ & $\begin{array}{c}\text { Relative } \\
\text { Frequency } \\
(\%)\end{array}$ \\
\hline $\begin{array}{l}\text { Infectious and parasitic diseases } \\
\text { Neoplasms (tumors) }\end{array}$ & 6 & 5,0 \\
$\begin{array}{l}\text { Diseases of the blood and hematopoie- } \\
\text { tic organs and immune disorders }\end{array}$ & 2 & 6,7 \\
$\begin{array}{l}\text { Nutritional endocrine and metabolic } \\
\text { diseases }\end{array}$ & 63 & 1,7 \\
Mental and behavioral disorders & 25 & 52,5 \\
$\begin{array}{l}\text { Diseases of the nervous system } \\
\text { Diseases of the eye and annexes }\end{array}$ & 12 & 20,8 \\
$\begin{array}{l}\text { Diseases of the circulatory system } \\
\text { Diseases of the respiratory system }\end{array}$ & 35 & 10,0 \\
$\begin{array}{l}\text { Diseases of the digestive system } \\
\text { Diseases of the skin and subcutaneous }\end{array}$ & 12 & 73,2 \\
tissue & 14 & 10,0 \\
Diseases of the osteomuscular system & 2 & 1,7 \\
and connective tissue & 76 & 63,3 \\
Diseases of the genitourinary system & 15 & 12,5 \\
\hline
\end{tabular}

Table 3. Absolute and relative frequency of the number of medications used by 120 elderly patients with chronic vestibular dysfunction.

\begin{tabular}{cccc}
\hline & Categories & $\begin{array}{c}\text { Absolute } \\
\text { Frequency } \\
(\mathrm{n})\end{array}$ & $\begin{array}{c}\text { Relative } \\
\text { Frequency } \\
(\%)\end{array}$ \\
\hline \multirow{4}{*}{$\begin{array}{c}\text { Number of } \\
\text { medications }\end{array}$} & $\begin{array}{c}\text { Non-user } \\
\text { 3 or } \text { or medications }\end{array}$ & 35 & 3,3 \\
& $\begin{array}{c}5 \text { or more medica- } \\
\text { tions }\end{array}$ & 37 & 29,2 \\
& & 44 & 36,8 \\
\hline
\end{tabular}

Twelve elderly patients (10.0\%) used walking aids.

64 elderly patients (53.3\%) had at least one fall during the last year. Of these $35(54.6 \%)$ reported recurrent falls. Most patients reported fear of falls (72.5\%) and the tendency to fall (79.2\%).

Topographic diagnosis of vestibular dysfunction by the vestibular exam was done in 105 of 120 elderly patients. Fifteen patients had not undertaken the vestibular exam until the time of assessment. The vestibular exam disclosed the following diagnoses, in order of prevalence: Vestibular Deficiency Syndrome in 39.0\% of cases (15.2\% in the right ear, $14.3 \%$ in the left ear and 9.5\% in both ears), Irritative Vestibular Syndrome in $32,4 \%$ of cases ( $4.8 \%$ in the right ear, $2.9 \%$ in the left ear, $12.4 \%$ in both ears and $12.4 \%$ which were undetermined), Normal in $20.0 \%$ of patients, 
Table 4. Absolute and relative frequency of medications used by 120 elderly patients with chronic vestibular dysfunction, according to the Anatomical Therapeutic Chemical Classification Index.

\begin{tabular}{lcc}
\hline & $\begin{array}{c}\text { Absolute } \\
\text { Frequency } \\
(\mathrm{n})\end{array}$ & $\begin{array}{c}\text { Relative } \\
\text { Frequency } \\
(\%)\end{array}$ \\
\hline Use of otoneurological drugs & 76 & 63,3 \\
Use of cardiovascular system drugs & 81 & 67,5 \\
Use of Gl tract and metabolic system & 46 & 38,3 \\
drugs & & \\
Use of drugs for the nervous system & 36 & 30,0 \\
Use of hematological system drugs & 44 & 36,7 \\
Use of muscle skeletal system drugs & 16 & 13,3 \\
Use of respiratory system drugs & 4 & 3,3 \\
Use of systemic hormone prepara- & 12 & 10,0 \\
tion drugs & & \\
Use of ophthalmologic drugs & 10 & 8,3 \\
Use of other drugs & 6 & 5,0 \\
\hline
\end{tabular}

Central Vestibular Syndrome in 7.6\% of cases, and Mixed Vestibular Syndrome in $1.0 \%$ of cases.

The prevalence of the number of vestibular conditions was classified as follows: one disease (45.0\%), two diseases (38.3\%) and three or more diseases (6.7\%). Vestibular diseases diagnosed in the sample of 120 patients are shown on Table 5 in decreasing order of prevalence.

VAS quantified reported self-perception of the intensity of dizziness in elderly patients with chronic vestibular dysfunction revealed an average of 6.62 points $(\mathrm{SD}=2.45)$, with zero as a minimum score and ten as a maximum score for some patients.

The time from onset of dizziness prevalence was 3 to 6 months (10.8\% of cases), 7 to 11 months (8.3\%), 1 to 2 years $(25.0 \%), 3$ to 4 years $(12.5 \%)$ and over 5 years (43.3\%).

Characterization of dizziness according to type, duration and periodicity is shown on Table 6 .

Activities, positions and predisposing symptoms of dizziness are shown in decreasing order on Table 7.

Associated auditory symptoms included hypersensitivity to sounds in 90 elderly patients (75.0\%), followed by tinnitus (70.8\%), auditory deficits (60.0\%), and a feeling of aural pressure/fullness (54.2\%). The prevalence of reported neurovegetative symptoms was sweating/pallor/tachycardia (43.3\%), nausea (43.3\%), vomiting (17.5\%) and presyncope (40.8\%). We highlight the importance of psychological symptoms in the elderly with vestibular disease, including anxiety $(74.2 \%)$, memory and concentration deficits (68.3\%) and fear (40.0\%). Other common signs and symptoms encountered in the sample were oscillopsia (59.2\%), insomnia (48.3\%) and headache (42.5\%).
Table 5. Absolute and relative frequency of vestibular conditions in 120 elderly patients with chronic vestibular dysfunction.

\begin{tabular}{lcc}
\hline & $\begin{array}{c}\text { Absolute } \\
\text { Frequency } \\
(\mathrm{n})\end{array}$ & $\begin{array}{c}\text { Relative } \\
\text { Frequency } \\
(\%)\end{array}$ \\
\hline Metabolic Labyrinthopathy & 48 & 40,0 \\
Benign Positional Paroxysmal Ver- & 44 & 36,7 \\
tigo & 27 & 22,5 \\
Vascular Labyrinthopathy & 22 & 18,3 \\
Idiopathic Cochleovestibular Syn- & & \\
drome & 19 & 15,8 \\
Vertebrobasilar Failure & 15 & 12,5 \\
Ménière's Disease & 13 & 10,8 \\
Presbivertigo/Presbiataxis/Presbitin- & & \\
nitus/Presbiacusis & 7 & 5,8 \\
Cervical Syndrome & 3 & 2,5 \\
Vestibular Migraine & 3 & 2,5 \\
Vestibular Schwannoma & 3 & 2,5 \\
Labyrinthic Trauma & 1 & 0,8 \\
Ototoxicosis & 1 & 0,8 \\
Immune Disease & 1 & 0,8 \\
Vestibular Neuritis & & \\
\hline
\end{tabular}

Table 6. Absolute and relative frequency of the type, duration and periodicity of dizziness in 120 elderly patients with chronic vestibular dysfunction.

\begin{tabular}{lccc}
\hline Categories & $\begin{array}{c}\text { Absolute } \\
\text { Frequency } \\
(\mathrm{n})\end{array}$ & $\begin{array}{c}\text { Relative } \\
\text { Frequency } \\
(\%)\end{array}$ \\
\hline Type of dizziness & $\begin{array}{c}\text { Rotating dizzi- } \\
\text { ness } \\
\text { Non-rotating } \\
\text { dizziness }\end{array}$ & 8 & 6,7 \\
& Both & 82 & 25,0 \\
Type of rotating & Subjective & 49 & 68,3 \\
dizziness & Objective & 35 & 40,8 \\
& Both & 6 & 29,2 \\
& No report & 30 & 5,0 \\
Duration of dizzi- & Days & 14 & 11,7 \\
ness & Hours & 23 & 19,2 \\
& Minutes & 45 & 37,5 \\
\hline \multirow{3}{*}{$\begin{array}{l}\text { Periodicity of } \\
\text { dizziness }\end{array}$} & Seconds & 38 & 31,7 \\
& Sporadic & 15 & 12,5 \\
& Monthly & 17 & 14,2 \\
\hline & Weekly & 33 & 27,5 \\
& Daily & 55 & 45,8 \\
\hline
\end{tabular}


Table 7. Absolute and relative frequency of predisposing activities, positions and symptoms of dizziness in 120 elderly patients with chronic vestibular dysfunction.

\begin{tabular}{lcc}
\hline & $\begin{array}{c}\text { Absolute } \\
\text { Frequency } \\
(\mathrm{n})\end{array}$ & $\begin{array}{c}\text { Relative } \\
\text { Frequency } \\
(\%)\end{array}$ \\
\hline Turning the head & 81 & 67,5 \\
Head in a specific position & 77 & 64,2 \\
Arising from decubitus & 70 & 58,3 \\
Walking & 69 & 57,5 \\
During exercise & 62 & 51,7 \\
Arising from the seated position & 60 & 50,0 \\
Turning the body from a sitting or & 54 & 45,0 \\
standing position & 53 & 44,2 \\
When anxious & 40 & 33,3 \\
Changing position in bed & 22 & 18,3 \\
Lying down on one side & 7 & 5,8 \\
Sitting still & & \\
\hline
\end{tabular}

\section{DISCUSSION}

The main social and demographic characteristics of our elderly patient sample were similar to those of other studies of elderly patients monitored in otoneurology outpatient clinics with a complaint of dizziness ${ }^{9-3}$, and similar to the profile of elderly persons dwelling in Brazilian urban regions according to Ramos et al. ${ }^{14}$

Ramos et al. ${ }^{14}$ found a relatively young population, with $58.0 \%$ of persons aged below 70 years and an average age of 69 years. However, in our sample of elderly patients with vestibular disease we found an older population, similar to Ebel's study. The average age was relatively high ( 73.4 years), similar to reports by Ebel $^{9}$ ( 74.3 years), Gushikem $^{10}$ ( 72.0 years), Cavalli ${ }^{11}$ ( 70.5 years) and Simoceli et al. ${ }^{13}$ ( 72.3 years).

Most of the elderly patients in our sample were women, which is similar to the findings of Ramos et al. ${ }^{14}$ in community dwelling elderly persons (60.0\%) and also similar to elderly patients with vestibular disease in outpatient clinics studied by $\operatorname{Ebel}^{9}$ (68.3\%), Gushikem ${ }^{10}$ (67.6\%) and Medeiros ${ }^{12}$ (64.5\%).

Campos ${ }^{15}$ reported that dizziness is more frequent in women in a 2:1 ratio. The association of vestibular disease, hormone dysfunction, and metabolic disorders in women and the fact that women tend to seek medical help more frequently than men could justify this prevalence ${ }^{16}$.

Over half of our elderly patient sample lived in multigeneration families, which is also similar to the findings of Ramos et al. ${ }^{14}$ in community dwelling elderly persons (59.0\%). However, we found no studies showing the housing arrangements of elderly patients with vestibular diseases to compare with our study.
Our elderly patient sample contained a high proportion of elderly persons with low education levels; only $17.5 \%$ had post-elementary schooling. This is similar to post-elementary schooling percentages found by Ramos et al. ${ }^{14}(18.0 \%)$ and Medeiros ${ }^{12}$ (11.9\%).

Ramos et al.'s ${ }^{14}$ population study revealed that most of the elderly persons (80.0\%) had at least one chronic disease, and that a small percentage of this group (10.0\%) had at least five diseases. In our elderly patient sample we found a prevalence of five or more chronic diseases, other than the vestibular syndrome, in $35.8 \%$ of patients. Our elderly patient sample included voluntary participants from an otoneurology outpatient clinic, which could mean a biased population with increased health problems compared to community dwelling elderly persons in general.

The main vestibular disease etiologies found in elderly patients in our study were metabolic and vascular causes, similar to observations by Mangabeira Albernaz ${ }^{17}$ and Ganança et al. ${ }^{18}$ in patients with dizziness, regardless of age. These numbers were also similar to studies of elderly patients with a complaint of dizziness monitored in outpatient settings $s^{9,10}$.

Metabolic labyrinth disease, particularly in the elderly, may arise from metabolic disorders such as hyperlipidemia, hyper or hypoglycemia, hyperinsulinism or insulinopenia, uremia, hyper or hypothyroidism, and ovarian hormonal alterations, among others. It may also be caused by dietary errors, which may lead to labyrinth disorders and/or act as significant aggravating factors. Metabolic disorders may promote vestibular symptoms varying from mild instability to clinical pictures similar to Ménière's disease $e^{5,15,19,20}$. Bittar et al. ${ }^{21}$ stated that in glucose metabolism, both hypoglycemia and hyperglycemia have a major influence on the inner ear, altering its usual function. Insulinemic alterations in the long term may be responsible for accelerating the development of atherosclerotic lesions in diabetes mellitus patients ${ }^{21}$, one of the most prevalent diseases in the elderly ${ }^{22}$.

According to Ganança et al. ${ }^{23}$, arterial hyper or hypotension, heart failure, myocardial infarction, arrhythmias, hypersensitivity of carotid sinus reflexes, aortic stenosis and atherosclerosis are the main circulatory disorders causing peripheral and/or central affections of the auditory and/or vestibular systems. Auditory and vestibular lesions tend to be attributed to ischemic disorders resulting from decreased blood perfusion, lower oxygen supply and/or intravascular obstacles (embolism and atherosclerosis).

An important point is that some of the vestibular diseases found in our elderly patient sample could also have been classified as having a vascular origin. This is due to compromise of blood flow to the peripheral and/or central vestibular systems, such as in the case of diabetes mellitus and hyperlipidemias - classified in this study as having a metabolic origin - and BPPV and vertebrobasilar failure. As 
such, vascular vestibular diseases would become the most common vestibular conditions in this age group.

We also found a higher prevalence of osteomuscular and connective tissue disorders in our elderly patient sample compared to findings by $\operatorname{Ebel}^{9}(38.3 \%)$ and Gushikem ${ }^{10}$ (41.2\%). Various aging conditions of the osteoarticular system such as physiological osteopenia, cartilaginous aging, sarcopenia and reduction in nerve conduction velocity are cited. Pain and muscle and skeletal disorders are the most frequent complaint presented by elderly patients, as the incidence of many rheumatological diseases, including osteoporosis, osteoarthritis, rheumatic polymyalgia and others, increases with age ${ }^{24}$.

Results of the vestibular exam in this study was similar to those found by Caovilla et al. ${ }^{25}$, in which $88.7 \%$ were peripheral vestibular syndromes, $11.0 \%$ were central vestibular syndromes, and 03.\% were mixed syndromes. In 43 patients with vestibular dysfunction and ages ranging from 14 to 88 years, Whitney et al. ${ }^{26}$ found that $79.0 \%$ were peripheral vestibular syndromes, $7.0 \%$ were central vestibular syndromes and $14.0 \%$ were multisensory conditions.

Ganança et al. ${ }^{27}$ and Sloane and Baloh ${ }^{28}$ reported that BPPV is the most common vestibular affection in the elderly. In our study the most prevalent affection was metabolic labyrinthopathy. The diagnostic hypothesis of metabolically originated vestibular disease was considered when patients presented alterations related to carbohydrate and/or lipid metabolism, altered uric acid values or altered thyroid and pancreatic hormone levels in the absence of other vestibular clinical pictures. As metabolic disorders are common in elderly patients, idiopathic conditions may have been inadequately classified as being metabolically, given the diagnostic exclusion process made to diagnose idiopathic affections by discarding other vestibular diseases.

Less common vestibular disorders in our elderly patient sample were ototoxicosis, immune diseases, vestibular neuritis, vestibular migraine, vestibular schawnnoma, labyrinthic trauma and cervical syndrome. These were similar findings to those of Caovilla et al. ${ }^{25}$ in a retrospective study of one thousand new consecutive patients from a private clinic, aged between 21 and 80 years, medically and otoneurologically diagnosed as having vestibular disorder.

Although there was a small prevalence of the cervical syndrome, it is important to emphasize that, upper cervical column osteoarticular pathophysiological mechanisms such as osteophytes, atlanto-occipital instability, and cervical root or articular facet inflammation or irritation may cause dizziness due to alterations in cervical proprioception $^{29}$.

The prevalence of vestibular affections in this study was $45.0 \%$ for one disease and was $55.0 \%$ for two or more diseases, similar to findings by Simoceli et al. ${ }^{13}$, in which
$49.0 \%$ of elderly patients had a single etiology and 51.0\% had two or more etiologies for imbalance, demonstrating the increased involvement of the vestibular system in this age group.

In our study most of the elderly patients used medication. Users of five or more medications were $36.7 \%$ of our sample, and the average was 3.86 medications per patient, similar to findings in elderly patients in a study by Gushikem ${ }^{10}$. Values found in our study were higher compared to those disclosed by Garcia ${ }^{30}$, who found that $72.0 \%$ of community dwelling elderly persons used medical medications, with an average 2.05 medications per patient. This is probably because elderly patients with vestibular disorders, having more health problems, require more medication.

The most common medical drugs used by our elderly patient sample were medications for the cardiovascular system, for GI tract conditions, for metabolic disorders, for hematological diseases and for nervous system affections. According to Garcia ${ }^{30}$, users of five or more medications were $11.2 \%$ of patients. The most common group of medications were those for the cardiovascular system, followed by medications for the GI tract, for metabolic disorders, for the nervous system and the hematological system. No published reports were found in literature reporting the most commonly used types of medications in elderly patients with vestibular diseases.

The incidence of falls in our elderly patient sample differed from population studies. Campbell et al.,31 Tinetti et al..$^{32}$, and Perracini and Ramos ${ }^{33}$ showed a $30.0 \%$ to $35.0 \%$ prevalence of falls during the last year in community dwelling elderly persons. Our elderly patient sample with vestibular disorders had a higher prevalence (53.3\%), similar to a study by Medeiros12 (59.2\%).

Recurring falls in our study were found in $29.2 \%$ of patients, different from a study by Perracini and Ramos ${ }^{33}$ in metropolitan Sao Paulo, where the prevalence was $11.0 \%$.

Vestibular originated dizziness may facilitate falls and recurrent falls. According to Herdman et al. ${ }^{34}$, vestibular dysfunction limits posture control, including stability and body alignment. These authors found a statistically significant higher number of falls in patients with bilateral vestibular dysfunction aged between 65 and 74 years compared to community dwelling elderly persons in the same age group.

There was a predominance of associated rotating and non-rotating dizziness in our patients, different from Caovilla et al.' $\mathrm{s}^{25}$ study in which rotating dizziness predominated.

Our elderly patient sample had long-term dizziness, similar to the study by Medeiros ${ }^{12}$, in which $77.6 \%$ patients reported dizziness for over one year. Sloane and Baloh $^{28}$ found that dizziness had an average duration of 
36.2 months, demonstrating the chronic nature of dizziness in the elderly population, and the difficulty of vestibular compensation in this age group.

Predisposing symptoms for dizziness reported in this study were turning the head, keeping the head in a specific position, arising from decubitus, walking, and anxiety, similar to findings by Tinetti et al. ${ }^{4}$, who described the most common positions or activities as being arising from decubitus, turning the head, turning the body, standing from a sitting position, and anxiety. These head movements and/or positions strongly stimulate the vestibular system and frequently produce vertigo and other forms of dizziness such as in BPPV, which is so prevalent in elderly patients.

Anxiety is a psychical symptom, different from motor activities related to head movements and balance control that predispose to dizziness. Psychic symptoms may be caused by psychic insecurity secondary to physical insecurity generated by balance disturbances ${ }^{35}$.

The prevalence of associated symptoms was higher in elderly patients in our study compared to the sample in Caovilla et al. ${ }^{25}$, study, in which the prevalence of associated symptoms in patients with vestibular diseases in general was $24.9 \%$ for tinnitus, $20.2 \%$ for hypoacusis, $18.3 \%$ for headaches, $14.1 \%$ for depression, $12.6 \%$ for memory disturbances, $12.6 \%$ for hypersensitivity to sounds sons, $12.5 \%$ for nausea, $10.3 \%$ for anxiety, $10.1 \%$ for presyncope, $10.1 \%$ for feeling of aural pressure/fullness, $9.5 \%$ for fear, $7.7 \%$ for sweating/pallor/tachycardia and $5.1 \%$ for vomiting. Our data agrees with Gushikem's ${ }^{10}$ findings, which reveal an association between dizziness and tinnitus in $79.4 \%$ of cases, hypoacusis in $55.9 \%$, sensitivity to loud sounds in $47.1 \%$, neurovegetative disturbances in $55.9 \%$ and syncope in $8.8 \%$ of cases in elderly patients with vestibular diseases. These findings corroborate the fact that elderly patients with vestibular diseases tend to have a concomitant presentation of other systems related to vestibular functioning, among which the auditory system.

\section{CONCLUSION}

The sample of elderly patients with chronic vestibular dysfunction assessed in this study included mostly women and a high average age, with associated diseases and polypharmacotherapy. The conditions most frequently associated with vestibular dysfunction were circulatory, nutritional endocrine, metabolic, and osteomuscular diseases. The most frequently used medications were cardiovascular and otoneurological drugs. The most frequent vestibular diseases and topography were metabolic and vascular labyrinthopathy and unilateral deficient peripheral syndrome. Dizziness was a chronic or long-term condition. The association between two vestibular disorders was common. The association between rotating and non-rotating dizziness was frequent. Falls and other symptoms were prevalent in this population.

\section{REFERENCES}

1. Ganança MM, Caovilla HH. Desequilíbrio e reequilíbrio. In: Ganança MM. Vertigem tem cura? São Paulo: Lemos Editorial; 1998. p.13-9.

2. Ganança MM, Caovilla HH, Munhoz MSL, Silva MLG, Frazza MM. As etapas da equilibriometria. In: Ganança MM, Caovilla HH, Munhoz MSL, Silva MLG. Equilibriometria Clínica. Série Otoneurologia. São Paulo: Editora Atheneu; 1999. p.41-114.

3. Ganança MM, Caovilla HH. A vertigem e sintomas associados. In Ganança MM, Vieira RM, Caovilla HH. Princípios de Otoneurologia. Série Distúrbios de Comunicação Humana. São Paulo: Editora Atheneu; 1998. p.3-5.

4. Tinetti ME, Williams CS, Gill TM. Dizziness among older adults: a possible geriatric syndrome. Ann Intern Med 2000;132(5):337-44.

5. Ganança MM, Caovilla HH, Munhoz MSL, Silva MLG, Ganança FF, Ganança CF. A vertigem explicada. RBM Rev Bras Med 1999;56(Espec):220.

6. Organização Mundial de Saúde. CID-10. Classificação estatística internacional de doenças e problemas relacionados à saúde. 8a ed. São Paulo: EDUSP; 2000; 1:1191p.

7. World Health Organization. Anatomical Therapeutic Chemical (ATC) Classification Index. WHO Collaborating Center for Drug Statistics Methodology; 1992.

8. The SAS Statistical Analysis System: system for Windows [computer program]. Version 6.12. Cary (NC): SAS; 1996.

9. Ebel SJ. Prevalência de Sintomas e Sinais Otoneurológicos em Pacientes Idosos com Queixa de Tonturas [Dissertação]. São Paulo: Universidade Federal de São Paulo - Escola Paulista de Medicina;1994.

10. Gushikem P. Avaliação Otoneurológica em Idosos com Tontura [Dissertação]. São Paulo: Universidade Federal de São Paulo - Escola Paulista de Medicina; 2001.

11. Cavalli SS. Avaliação da qualidade de vida em Idosos com tontura que apresentaram e não apresentaram quedas. [Dissertação]. São Paulo: Universidade Bandeirantes de São Paulo; 2003.

12. Medeiros RFR. Estudo da Berg Balance Scale em idosos vestibulopatas. [Dissertação]. São Paulo: Universidade Bandeirantes de São Paulo; 2003.

13. Simoceli L, Bittar RMS, Bottino MA, Bento RF. Diagnostic approach of balance in the elderly: preliminary results. Rev bras otorrinolaringol 2003;69(6):772-7.

14. Ramos LR, Rosa TEC, Oliveira ZM, Medina MCG, Santos FRG. Perfil do idoso em área metropolitana na região sudeste do Brasil: resultados de inquérito domiciliar. Rev Saúde Pública 1993;27(2):87-94.

15. Campos CAH. Principais quadros clínicos no adulto e no idoso. In: Ganança MM. Vertigem tem cura? São Paulo: Lemos Editorial; 1998. p. $49-57$.

16. Pedalini MEB, Bittar RSM, Formigoni LG, Cruz OLS, Bento RF, Miniti A. Reabilitação vestibular como tratamento da tontura: experiência com 116 casos. Arquivos da Fundação Otorrinolaringologia 1999;2(2):748.

17. Mangabeira Albernaz PL. Aspectos otoneurológicos na velhice. Acta AWHO 1982; 1(3):93-5.

18. Ganança MM, Caovilla HH, Munhoz MSL, Silva MLG, Settanni FAP, Ganança FF, et al. As tonturas e sintomas associados. In: Munhoz MSL, Ganança MM, Caovilla HH, Silva MLG. Casos Clínicos Otoneurológicos Típicos e Atípicos. São Paulo: Editora Atheneu; 2001. p.1-22.

19. Freitas MR, Weckx LLM. Como diagnosticar e tratar labirintopatias. RBM Rev Bras Med 1998;54:173-84.

20. Bittar RSM, Bottino MA, Zerati FE, Moraes CLO, Cunha AU, Bento RF. Prevalência das alterações metabólicas em pacientes portadores de queixas vestibulares. Rev Bras Otorrinolaringol 2003;69(1):64-8.

21. Bittar RSM, Sanchez TG, Santoro PP, Medeiros IRT. O metabolismo da glicose e o ouvido interno. Arquivos da Fundação Otorrinolaringologia 1998;2(1):4-8.

22. Nasri F. Diabetes Mellitus no Idoso. In: Freitas EV, Py L, Neri AL, 
Cançado FAX, Gorzoni ML, Rocha SM. Tratado de Geriatria e Gerontologia. Rio de Janeiro: Editora Guanabara Koogan; 2002. p.496-501.

23. Ganança MM, Caovilla HH, Munhoz MSL, Silva MLG, Settanni FAP. Vestibulopatias de origem cardiovascular. In: Silva MLG, Munhoz MSL, Ganança MM, Caovilla HH. Quadros clínicos otoneurológicos mais comuns. Série Otoneurológica vol. 3. São Paulo: Editora Atheneu; 2000. p.55-61.

24. Sader CS, Rossi E. O envelhecimento do sistema osteoarticular. In: Freitas EV, Py L, Neri AL, Cançado FAX, Gorzoni ML, Rocha SM. Tratado de Geriatria e Gerontologia. Rio de Janeiro: Editora Guanabara Koogan; 2002. p.508-14.

25. Caovilla HH, Ganança MM, Munhoz MSL, Silva MLG, Frazza MM. O valor da nistagmografia computadorizada. Rev Bras Med Otorrinolaringol 1997;4(5):158-63.

26. Whitney S, Wrisley D, Furman J. Concurrent validity of the Berg Balance Scale and the Dynamic Gait Index in people with vestibular dysfunction. Physiother Res Int 2003;8(4):178-86.

27. Ganança MM, Caovilla HH, Munhoz MSL, Silva MLG. Alterações da audição e do equilíbrio corporal no idoso. RBM rev bras med 1999;56(10):995-1011.

28. Sloane PD, Baloh RW. Persistent dizziness in geriatric patients. J Am Geriatr Soc 1989:37(11):1031-8
29. Clendaniel RA. Vertigem Cervical. In: Herdman SJ. Reabilitação Vestibular. São Paulo: Editora Manole; 2002. p.490-504.

30. Garcia JT. Padrão de uso de medicamentos em idosos residentes na comunidade urbana: a importância de polimedicação (projeto EPIDOSO) [Dissertação]. São Paulo: Universidade Federal de São Paulo / Escola Paulista de Medicina; 2000.

31. Campbell AJ, Reinken J, Allan BC, Martinez GS. Falls in old age: a study of frequency and related clinical factors. Age ageing 1981;10:264-70

32. Tinetti ME, Speechley M, Ginter SF. Risk factors for falls among elderly persons living in the community. N Engl J Med 1988;319(26):17017.

33. Perracini MR, Ramos LR. Fatores associados a quedas em uma coorte de idosos residentes na comunidade. Rev Saúde Pública 2002;6(36):709-16.

34. Herdman SJ, Blatt P, Schubert MC, Tusa RJ. Falls in patients with vestibular deficits. Am J Otol 2000;21(6):847-51.

35. Caovilla HH, Ganança MM, Munhoz MSL, Silva MLG, Frazza MM Dicas sobre vestibulopatias periféricas e centrais. Rev Bras Med Otorrinolaringol 1998;5(2):50-4 